\title{
Pengaruh Concept Attainment Model Terhadap Disposisi Berpikir Kritis Matematis Mahasiswa
}

\author{
Lilis Marina Angraini \\ Pendidikan Matematika FKIP Universitas Islam Riau, Jl. Kaharuddin Nasution \\ No.113 Marpoyan Pekanbaru - Riau; lilismarina89@gmail.com
}

\begin{abstract}
Dikirim: 13 September 2018;Diterima: 26 September 2018;Dipublikasikan: 30 September 2018 Cara sitasi: Angraini, L.M. 2018. Pengaruh Concept Attainment Model terhadap Disposisi Berpikir Kritis Matematis Mahasiswa. JNPM (Jurnal Nasional Pendidikan Matematika) Vol. 2(2), Hal. 284-295.
\end{abstract}

\begin{abstract}
Abstrak. Penelitian ini bertujuan untuk melihat perbedaan disposisi berpikir kritis matematis mahasiswa melalui pembelajaran Concept Attainment Model dan pembelajaran konvensional. Analisis data menggunakan uji Kolmogorov-Smirnov, uji Levene, Uji t. Hasil penelitian ini menunjukkan bahwa tidak terdapat perbedaan disposisi berpikir kritis matematis mahasiswa kelas eksperimen dengan kelas konvensional secara keseluruhan. Untuk kedepannya disarankan penerapan Concept Attainment Model dilakukan dalam jangka waktu satu semester dan jumlah mahasiswa satu kelas tidak lebih dari 30 orang agar mendapatkan hasil penelitian yang maksimal.
\end{abstract}

Kata kunci : Concept Attainment Model, Disposisi Berpikir Kritis.

\begin{abstract}
Abstrak. This study aims to see differences in students' critical thinking dispositions through the learning of Concept Attainment Model and conventional learning. Data analysis using Kolmogorov-Smirnov test, Levene test, $\mathrm{t}$ test. The results of this study indicate that there is no difference in the mathematical thinking disposition of students in the experimental class with the conventional class as a whole. In the future it is recommended that the implementation of the Concept Attainment Model be carried out within one semester and the number of students in one class is no more than 30 people in order to obtain maximum research results.
\end{abstract}

Keyword: Concept Attainment Model, Disposition of Critical Thinking

\section{Pendahuluan}

Committee on the Undergraduate Program in Mathematics (CUPM) (MAA, 2004) memberikan enam rekomendasi dasar untuk jurusan, program, dan mata kuliah dalam matematika. Salah satu rekomendasinya menerangkan bahwa 
setiap mata kuliah dalam matematika hendaknya merupakan aktivitas yang akan membantu mahasiswa dalam pengembangan analitis, penalaran kritis, pemecahan masalah, keterampilan komunikasi dan disposisi berpikir kritis matematis. Rekomendasi CUPM di atas menerangkan, tugas lembaga pendidikan yang bertugas mendidik calon guru yang akan mengajarkan matematika, diantaranya adalah mempersiapkan mahasiswa-mahasiswinya untuk memiliki kemampuan komunikasi dan berpikir kritis matematis serta disposisi berpikir kritis matematis. Lembaga Pendidikan Tinggi Kependidikan (LPTK), Pendidikan Guru Sekolah Dasar (PGSD) yang bertugas melahirkan calon guru yang akan mengajarkan matematika ikut bertanggung jawab mempersiapkan mahasiswa-mahasiswinya untuk memiliki kemampuan komunikasi dan berpikir kritis matematis serta disposisi berpikir kritis matematis.

Perlunya dikembangkan sikap menghargai kegunaan matematika dalam kehidupan, yaitu memiliki rasa ingin tahu, perhatian, dan minat dalam mempelajari matematika, serta sikap ulet dan percaya diri dalam memecahkan masalah (Departemen Pendidikan Nasional, 2006). Pengembangan ranah afektif tersebut pada hakekatnya untuk menumbuhkembangkan disposisi matematis. Pentingnya pengembangan disposisi matematis sesuai dengan pernyataan Sumarmo (2010) bahwa dalam belajar matematika siswa dan mahasiswa perlu mengembangkan kemampuan berpikir dan disposisi berpikir kritis matematis. Pengembangan tersebut menjadi semakin penting manakala dihubungkan dengan tuntutan kemajuan IPTEKS dan suasana bersaing yang semakin ketat terhadap lulusan semua jenjang pendidikan.

Disposisi matematis mahasiswa berkembang ketika mereka mempelajari aspek kompetensi matematis (Noto dkk, 2015). Sebagai contoh, ketika mahasiswa membangun kompetensi strategi dalam menyelesaikan persoalan non-rutin, banyak konsep yang dipelajari dan dipahami, sehingga persoalan tersebut dapat diselesaikan, pada akhirnya matematika itu dapat dikuasai. Sebaliknya, bila mahasiswa jarang diberikan tantangan berupa persoalan matematika untuk diselesaikan, mereka cenderung menjadi menghafal daripada mengikuti cara-cara belajar matematika yang semestinya. Dari contoh tersebut menimbulkan dua sikap yang berbeda. Perlakuan contoh 
pertama akan menimbulkan sikap percaya diri karena mahasiswa mampu menyelesaikan masalah matematis. Perlakuan yang kedua akan menimbulkan sikap mudah menyerah ketika dihadapkan pada masalah, karena mahasiswa tidak terlatih menghadapi tantangan.

Menurut Bruner (dalam Ostad \& Soleymanpour, 2014) proses belajar akan berjalan dengan baik dan kreatif, jika dosen memberi kesempatan kepada mahasiswa untuk menemukan suatu aturan (termasuk konsep, teori, definisi, dan sebagainya) melalui contoh-contoh yang menggambarkan/ mewakili aturan yang menjadi sumbernya, dengan kata lain, mahasiswa dibimbing secara induktif untuk memahami suatu kebenaran umum.

Proses belajar yang dikemukakan oleh Bruner di atas sejalan dengan teori concept attainment model menurut Joyce \& Weil (1992), concept attainment model lebih menitikberatkan pada cara-cara untuk memperkuat dorongandorongan internal manusia dalam memahami ilmu pengetahuan, dengan cara menggali dan mengorganisasikan, serta mengembangkan bahasa untuk mengungkapkannya.

Bruner, Goodnow, dan Austin mengungkapkan concept attaiment model sengaja dirancang untuk membantu mahasiswa mempelajari konsep-konsep yang dapat dipakai untuk mengorganisasikan informasi, sehingga dapat memberi kemudahan bagi mahasiswa untuk mempelajari konsep itu dengan cara yang lebih efektif (Anjum, 2014).

Concept attainment model mempunyai beberapa tahapan pembelajaran, tahapan-tahapan dalam concept attainment model membantu mahasiswa dalam melatih kemampuan komunikasi dan berpikir kritis matematis. Tahapan pembelajaran pertama, yaitu penyajian data dan identifikasi konsep, pada tahap ini mahasiswa diminta membandingkan ciri-ciri dalam contoh dan non contoh, Tahapan kedua yaitu tahapan pengetesan pencapaian konsep, pada tahap ini mahasiswa diminta mengidentifikasi contoh-contoh konsep dan membuat contoh tambahan.

Tahap ketiga yaitu tahap analisis strategi berpikir, pada tahap ini mahasiswa terlatih untuk mengkomunikasikan matematikanya, karena mahasiswa 
diminta untuk mengungkapkan konsep dengan kata-kata sendiri, mengungkapkan alasan-alasan yang berkenaan dengan membuat contoh tambahan, dan menuliskan langkah-langkah penyelesaian soal dari konsepkonsep yang sedang dipelajari, serta merumuskan konsep matematikanya, sehingga dengan model pembelajaran yang dikemukakan oleh Bruce, et al ini, secara teoritis diyakini bahwasanya kemampuan disposisi berpikir kritis matematis mahasiswa menjadi lebih baik.

Kauchak dan Eggen mengemukakan concept attainment model adalah suatu model pembelajaran induktif yang didesain dosen untuk membantu mahasiswa dalam mempelajari konsep dan melatih keterampilan mahasiswa dalam mempraktekkan keterampilan berpikir tingkat tinggi (Bhargava, 2016). Concept attainment model sangat relevan dalam mengajarkan matematika (Mondal, 2013), karena concept attainment model dapat membantu perkembangan pemahaman dan penghayatan mahasiswa terhadap konsep, prinsip sehingga tumbuh daya nalar, berpikir logis, kritis, sistematis dan lain-lain.

Concept attainment model adalah suatu model pembelajaran yang bertujuan untuk membantu mahasiswa memahami suatu konsep tertentu, model pembelajaran ini lebih tepat digunakan ketika penekanan pembelajaran lebih dititikberatkan pada pengenalan konsep baru, sehingga dapat melatih kemampuan berpikir tingkat tinggi (Sharma \& Pachauri, 2016).

Beberapa pendapat di atas menunjukkan bahwa concept attainment model merupakan suatu model pembelajaran yang dirancang untuk membantu mahasiswa mempelajari konsep sehingga mahasiswa mampu menemukan konsep sendiri dan mengungkapkan secara bahasa maksud dari konsep yang ditemukannya, dengan demikian disposisi berpikir kritis matematis mahasiswa dalam pembelajaran matematika menjadi lebih baik, sehingga penelitian ini berjudul "Pengaruh Concept Attainment Model terhadap Disposisi Berpikir Kritis Matematis Mahasiswa PGMI". Adapun rumusan masalah dalam penelitian ini adalah: apakah terdapat perbedaan disposisi berpikir kritis matematis mahasiswa yang memperoleh pembelajaran concept attainment model dengan mahasiswa yang memperoleh pembelajaran konvensional? 


\section{Metode Penelitian}

Desain rencana penelitian untuk eksperimen ini diilustrasikan sebagai berikut:

$\mathrm{X}$

$\mathrm{O}$

$\mathrm{O}$

Sumber : (Ruseffendi, 2005)

Keterangan :

O : pemberian tes (tes kemampuan komunikasi dan berpikir kritis matematis)

X : pembelajaran Concept Attainment Model

Lokasi penelitian adalah di Universitas Negeri Islam (UIN) Syarif Hidayatullah Jakarta. Populasi penelitian adalah seluruh mahasiswa Pendidikan Guru Madrasah Ibtida'iyah (PGMI) semester V yang terdapat di UIN Syahid. Semua populasi tersebut dipilih sebagai sampel penelitian, yakni satu kelas kontrol dan satu kelas eksperimen.

Materi yang diteskan adalah bangun datar yang terdapat pada mata kuliah Pendidikan Matematika II. Skala disposisi berpikir kritis matematis digunakan untuk melihat perbedaan disposisi berpikir kritis matematis mahasiswa pada kedua kelompok pembelajaran. Skala sikap yang dipakai dalam penelitian ini adalah model skala Likert, dimana setiap pernyataan dilengkapi lima pilihan jawaban yaitu sangat Sangat Sering (SS), Sering (S), Jarang (J), Tidak Sering (TS), dan Sangat Tidak Sering (STS).

Perhitungan skor disposisi berpikir kritis matematis mahasiswa dilakukan dengan metode yang dapat digunakan untuk mengkuantifikasi data kualitatif ordinal adalah Deviasi Normal.

\section{Hasil dan Pembahasan}

Disposisi berpikir kritis matematis matematis merupakan keterkaitan dan apresiasi terhadap matematika, disposisi berpikir kritis matematis merupakan kecenderungan untuk berpikir dan bertindak dengan cara yang positif. Disposisi berpikir kritis matematis mahasiswa terhadap matematika terwujud melalui disposisi dan tindakan dalam memilih pendekatan menyelesaikan tugas yang dilakukan dengan percaya diri, keingintahuan mencari alternatif, tekun, dan tertantang serta kecenderungan mahasiswa merefleksi cara berpikir yang dilakukannya. 
Proses belajar yang bisa meningkatkan pencapaian disposisi berpikir kritis matematis mahasiswa, sehingga indikator-indikator yang menggambarkan pencapaian disposisi matematis mahasiswa tercapai adalah pembelajaran dengan concept attainment model.

Concept attainment model memiliki sistem sosial, sistem sosial concept attainment model ialah situasi atau suasana, dan norma yang berlaku dalam model pencapaian konsep. Model ini memiliki struktur yang moderat, dosen melakukan pengendalian terhadap aktivitas mahasiswa, tetapi dapat dikembangkan menjadi kegiatan dialog bebas dalam fase itu, dengan pengorganisasian kegiatan itu, diharapkan mahasiswa akan lebih memperhatikan inisiatifnya untuk melakukan proses induktif, bersamaan dengan bertambahnya pengalaman dalam melibatkan diri dalam proses pembelajaran sehingga pencapaian disposisi berpikir kritis matematis mahasiswa lebih baik.

Selanjutnya prinsip-prinsip pengelolaan atau reaksi dari concept attainment model adalah (a) Memberikan dukungan dengan menitikberatkan pada sifat hipotesis dari diskusi-diskusi yang berlangsung; (b) Memberikan bantuan kepada mahasiswa dalam mempertimbangkan hipotesis; (c) Memusatkan perhatian mahasiswa terhadap contoh-contoh yang spesifik; dan (d) Memberikan bantuan kepada mahasiswa dalam mendiskusikan dan menilai strategi berpikir yang mereka pakai. Dengan adanya prinsip-prinsip pengelolaan /reaksi dari concept attainment model diyakini pencapaian disposisi berpikir kritis matematis mahasiswa lebih baik.

Sistem pendukung concept attainment model ialah segala sarana, bahan dan alat yang diperlukan untuk melaksanakan concept attainment model. Sarana pendukung yang diperlukan dapat berbentuk gambar, foto, diagram, slide, tape, LKS, dan data yang terpilih dan terorganisasikan dalam bentuk unitunit yang berfungsi memberikan contoh-contoh. Sistem pendukung ini juga bertujuan untuk meningkatkan pencapaian disposisi berpikir kritis matematis mahasiswa.

Sistem yang diperlukan dalam concept attainment model ini adalah sistem yang banyak memberikan contoh dan bukan contoh. Sistem pendukung ini diperlukan agar mahasiswa melihat contoh yang cukup, dan pada akhirnya menguasai konsep yang terdapat pada contoh-contoh tersebut. Jadi, mahasiswa bukan menemukan konsep baru, tetapi menguasai konsepkonsep yang sudah ada, melalui pengamatan terhadap contoh-contoh. Dengan adanya tahapan-tahapan dan sistem-sistem yang ada dalam concept 
attainment model secara teoritis diyakini bahwa terjadi pencapaian disposisi berpikir kritis matematis mahasiswa melalui concept attainment model.

Di sisi lain pembelajaran model konvensional yang dimaksud dalam penelitian ini adalah pembelajaran yang biasa dilakukan dikelas. Pembelajaran yang biasa dilakukan meliputi tahapan-tahapan berikut: (1) dosen menjelaskan materi; (2) dosen memberikan contoh; terakhir (3) dosen memberikan latihan.

Tahapan-tahapan dalam model pembelajaran konvensional ini tidak memberikan kesempatan mahasiswa untuk melatih disposisi berpikir kritis matematis mahasiswa, sehingga secara teoritis pencapaian disposisi berpikir kritis matematis mahasiswa, dengan penerapan concept attainment model lebih baik dibandingkan penerapan pembelajaran model konvensional.

Agar memperoleh gambaran kualitas disposisi berpikir kritis matematis kedua kelompok mahasiswa tersebut, maka data dianalisis secara deskriptif, sehingga dapat diketahui rerata, deviasi standar, nilai minimum, dan nilai maksimum. Rangkuman hasil analisis deskriptif data disposisi berpikir kritis matematis mahasiswa pada kedua pembelajaran disajikan pada tabel berikut.

Tabel 1

Deskripsi Data Disposisi Berpikir Kritis Matematis

\begin{tabular}{ccc}
\hline Statistik Deskriptif & Kontrol (PK) & Eksperimen (CAM) \\
\hline$N$ & 38 & 44 \\
$\bar{X}$ & 81,33 & 83,30 \\
$S d$ & 6,64 & 8,52 \\
Min & 67,02 & 71,75 \\
Max & 101,99 & 103,07 \\
\hline
\end{tabular}

Pada tabel di atas, dapat dilihat bahwa deskripsi data disposisi berpikir kritis matematis kelas kontrol dan kelas eksperimen tidak terlalu jauh berbeda secara rata-rata. Namun, deviasi standar kelas eksperimen lebih besar daripada standar deviasi kelas kontrol.

Sebelum dilakukan uji-t, terlebih dahulu akan diuji normalitas data dan homogenitas varians dari disposisi berpikir kritis matematis mahasiswa 
berdasarkan pada pembelajaran CAM (kelas eksperimen) dan PK (kelas kontrol). Rumusan hipotesis untuk menguji normalitas data adalah:

H0: Data sampel berasal dari populasi yang berdistribusi normal

H1: Data sampel berasal dari populasi yang tidak berdistribusi normal

Kriteria pengujian yang digunakan adalah jika nilai probabilitas (sig.) lebih besar dari $\alpha=0,05$ maka H0 diterima, untuk kondisi lainnya H0 ditolak. Uji normalitas data yang digunakan adalah uji Kolmogorov-Smirnov. Hasil uji normalitas data disposisi berpikir kritis matematis mahasiswa kedua kelompok pembelajaran disajikan pada tabel berikut:

Tabel 2. Uji Normalitas Disposisi Berpikir Kritis Matematis

\begin{tabular}{ccc}
\hline Kolmogorov-smirnov & Kontrol (PK) & Eksperimen (CAM) \\
\hline $\mathrm{N}$ & 38 & 44 \\
Sig. & 0,81 & 0,28 \\
Keterangan & Hoditerima & Hoditerima \\
\hline
\end{tabular}

Dari tabel di atas, terlihat bahwa nilai signifikansi disposisi berpikir kritis matematis pada kedua pembelajaran lebih besar dari 0,05. Ini berarti hipotesis nol diterima. Artinya, data disposisi berpikir kritis matematis mahasiswa baik untuk kelas kontrol maupun kelas eksperimen berasal dari populasi yang berdistribusi normal. Selanjutnya akan diuji homogenitas varians disposisi berpikir kritis kedua kelompok sampel dengan menggunakan uji Levene. Rumusan hipotesis statistik untuk menguji homogenitas varians kedua kelompok data adalah:

$\mathrm{H}_{0}: \sigma_{1}^{2}=\sigma_{2}^{2}$

$\mathrm{H}_{1}: \sigma_{1}^{2} \neq \sigma_{2}^{2}$

Kriteria pengujian yang digunakan adalah: jika nilai probabilitas (sig.) lebih besar dari $\alpha=0,05$ maka $\mathrm{H}_{0}$ diterima, untuk kondisi lainnya $\mathrm{H}_{0}$ ditolak. Hasil uji homogenitas varians data disposisi berpikir kritis matematis mahasiswa kedua kelompok pembelajaran disajikan pada tabel berikut:

Tabel 3. Uji Homogenitas Data Disposisi Berpikir Kritis Mahasiswa

\begin{tabular}{ccc}
\hline Uji Levene & Data & Kriteria \\
\hline $\mathrm{N}$ & 82 & Ho ditolak \\
Sig. & 0,03 & \\
\hline
\end{tabular}


Dari di atas, terlihat bahwa nilai signifikansi disposisi berpikir kritis matematis pada kedua kelompok pembelajaran lebih kecil dari 0,05. Ini berarti hipotesis nol ditolak. Artinya varians kedua kelompok sampel tidak homogen. Selanjutnya karena varians kedua kelompok sampel tidak homogen, maka uji kesetaraan rata-rata disposisi berpikir kritis matematis dilakukan dengan menggunakan uji-t'. Rumusan hipotesis statistik yang diuji adalah:

H0: $\mu 1=\mu 2$

H1: $\mu 1 \neq \mu 2$

Dengan

$\mu 1=$ Rerata disposisi berpikir kritis matematis mahasiswa yang mendapat pembelajaran PK

$\mu 2=$ Rerata disposisi berpikir kritis matematis mahasiswa yang mendapat pembelajaran CAM

Kriteria pengujian yang digunakan adalah: jika p-value (sig.) lebih besar dari 0,05, maka H0 diterima; untuk kondisi lainnya HO ditolak. Hasil uji kesetaraan rata-rata data disposisi berpikir kritis matematis mahasiswa berdasarkan model pembelajaran disajikan pada tabel berikut.

Tabel 4. Uji Kesetaraan Data Disposisi Berpikir Kritis Matematis

\begin{tabular}{ccc}
\hline Uji-t' & Data & Kriteria \\
\hline $\mathrm{N}$ & 82 & Ho diterima \\
Sig & 0,25 & \\
\hline
\end{tabular}

Dari tabel di atas, terlihat bahwa nilai signifikansi uji-t' lebih besar dari 0,05, sehingga $\mathrm{H}_{0}$ diterima. Artinya tidak terdapat perbedaan secara signifikan antara rerata disposisi berpikir kritis matematis mahasiswa yang mendapat pembelajaran CAM (kelas eksperimen) dan mahasiswa yang mendapat pembelajaran PK (kelas kontrol). Hal ini menggambarkan bahwa meskipun standar deviasi disposisi berpikir kritis kelas eksperimen lebih tinggi dibandingkan kelas control, namun secara keseluruhan disposisi berpikir kritis matematis kelas eksperimen dan kelas kontrol tidak terdapat perbedaan secara signifikan.

\section{Kesimpulan dan Saran}

JNPM (Jurnal Nasional Pendidikan Matematika) Vol. 2, No. 2, Hal. 284-295

p-ISSN 2549-8495, e-ISSN 2549-4937@Prodi Pendidikan Matematika Unswagati Cirebon 
Adapun keterbatasan yang ditemukan dalam penelitian ini adalah sebagai berikut: (1) Waktu penelitian yang hanya enam kali pertemuan dan satu kali pertemuan untuk tes, membuat keterbatasan mahasiswa dalam mengembangkan disposisi berpikir kritis matematis yang membutuhkan latihan secara terus menerus agar mahasiswa menjadi semakin kritis dalam pembelajaran. Waktu pelaksaaan yang berlangsung selama 2 bulan belum terlalu membuat mahasiswa terbiasa belajar dengan pembelajaran yang menggunakan concept attainment model, agar hasilnya sesuai dengan yang diharapkan, sebaiknya waktu penelitian lebih di perpanjang lagi. Banyaknya mahasiswa yang terlambat masuk kelas, sehingga efektivitas waktu pembelajaran tidak maksimal, seharusnya waktu pembelajaran 2,5 jam namun karena banyak mahasiswa terlambat rata-rata pembelajaran hanya berjalan selama 2 jam setiap kali pertemuan. Dosen terkendala pada mahasiswa yang datang terlambat, karena mereka tidak bisa menyeimbangkan materi dengan teman-temanya. Apalagi jika ada mahasiswa yang tidak hadir pada pertemuan sebelumnya, hal ini membuat dosen harus menjelaskan pada mahasiswa tersebut mengenai materi sebelumnya. (3) Masih banyak mahasiswa dikelas eksperimen yang belum mengerti konsep dasar operasi aljabar, sehingga selama pembelajaran peneliti lebih disibukkan dengan pembetulan konsep-konsep yang masih salah, akibatnya pembelajaran dengan concept attainment model kurang efektif karena kemampuan mahasiswa yang tidak seimbang. Pembelajaran dengan menggunakan concept attainment model ini lebih menekankan kepada penemuan konsep oleh masing-masing individu. Karena banyak mahasiswa yang masih salah dengan konsep dasar matematisnya maka pembelajaran semakin terkendala, dosen harus memperbaiki konsep-konsep yang masih salah, kemudian baru bisa melanjutkan materi pembelajaran. (4) Banyaknya jumlah mahasiswa dalam 1 kelas (kelas eksperimen), yaitu 44 orang mahasiswa, sehingga peneliti agak kewalahan dalam memberikan stimulusstimulus agar mereka bisa mencapai konsep. Dari 44 mahasiswa tersebut, hanya sekitar 15 orang mahasiswa yang mempunyai konsep dasar matematis yang baik. Selama pembelajaran dosen mendatangi mahasiswamahasiswa (yang konsep dasar matematisya belum cukup baik) satu per satu untuk memberikan stimulus-stimulus tentang materi pembelajaran agar mahasiswa tetap mencapai konsepnya sendiri. (5) Mahasiswa PGMI semester 5 bukanlah mahasiswa yang secara keseluruhan memiliki minat 
belajar dalam matematika. Selanjutnya di semester 7 mereka akan dikelompokkan sesuai dengan peminatan masing-masing. Dari 44 mahasiswa kelas eksperimen, hanya sekitar 15 orang yang berkeinginan masuk penjurusan matematika, selainnya memilih ingin masuk penjurusan bahasa Indonesia dan IPA. Mereka yang akan memilih penjurusan matematika, selama pembelajaran terlihat antusias dalam mengikuti materi pelajaran. Namun mereka yang memilih penjurusun IPA terutama bahasa Indonesia kurang antusias selama pembelajaran, selain karena konsep dasar matematika mereka yang masih salah, mereka juga menyatakan belajar matematika itu memusingkan, dan nanti juga mereka tidak ingin menjadi guru Madrasah Ibtida'iyah (MI) yang mengajarkan matematika. Dari sini terlihat minat sebagian besar dari mereka dalam belajar matematika kurang baik. (1) Tidak adanya observer selama pembelajaran berlangsung. Kegiatan obesrvasi adalah kegiatan yang bertujuan untuk memantau atau menilai apakah proses pembelajaran berlangsung dengan baik atau tidak. Kegiatan observasi ini seharusnya dilakukan oleh orang ketiga (selain peneliti dan obek yang diteliti), dalam hal ini yang menjadi observer adalah dosen pengampu mata kuliah Pendidikan Matematika II. Namun karena beliau berhalangan hadir untuk memantau proses pembelajaran, tidak ada kegiatan observasi selama pembelajaran. Akibatnya peneliti tidak bisa menilai kegiatan pembelajaran yang dilakukan oleh peneliti sendiri sudah cukup baik atau belum. (2) Mahasiswa terbiasa belajar menerima materi pelajaran. Mahasiswa biasanya memperhatikan, dan dosen menjelaskan serta menggunakan powerpoint. Kebiasaan belajar seperti ini membuat mahasiswa belum terbiasa dan kesulitan belajar dengan pembelajaran concept attainment model, karena pembelajaran dengan menggunakan model ini menuntut mahasiswa untuk menemukan konsep sendiri tanpa dijelaskan dosen secara langsung.

\section{Daftar Pustaka}

Anjum, S. K. (2014). A Study of effect of concept attainment model on achievement of geometric concepts of VIII standard students of english medium students of Aurangabad City. An International Peer Reviewed. Vol-II/XV.

Bhargava, R. (2016). Effect of concept attainment model on achievement in social sciences. International Journal of Science and Research. Vol.5. Issue.5.

JNPM (Jurnal Nasional Pendidikan Matematika) Vol. 2, No. 2, Hal. 284-295

p-ISSN 2549-8495, e-ISSN 2549-4937@Prodi Pendidikan Matematika Unswagati Cirebon 
Departemen Pendidikan Nasional. (2006). Kurikulum Tingkat Satuan Pendidikan. Jakarta: Pusat Kurikulum Balitbang Depdiknas.

Joyce \& Weil. (1992). Models of teaching. Boston: Allyn and Bacon.

Mathematics Association of America. (2004). Undergraduate programs and courses in the mathematical sciences: CUPM Curriculum Guide 2004.Washington DC: The Mathematics Association of America Published.

Mondal, B.C. (2013). Teaching science through information processing model: a review. Journal of Education and Practice. Vol.4, No.9.

Noto, M. S., Tonah \& Hernati. (2015). Efektivitas pendekatan metakognitif terhadap kemandirian belajar dan berpikir kritis matematis siswa. Jurnal Penelitian dan Pembelajaran Matematika (JPPM). 8 (1). 47-52.

Ostad, G. \& Soleymanpour, J. (2014). The impact of concept attainment teaching model and mastery teaching method on female high school students' academic achievement and metacognitive skilss. International Journal of Innovative Research in Science, Engineering and Technology. Vol.3. Issue.2.

Ruseffendi, E.T. (2005). Dasar-dasar Penelitian Pendidikan dan Bidang Noneksakta Lainnya.. Bandung: Tarsito.

Sharma, A. \& Pachauri, D. (2016). Comparison of advance organizer and concept attainment model for teaching concepts of science to standard IX. International Journal of Educational Research and Technology. Vol.7, No.1.

Sumarmo, U. (2010). Berpikir dan disposisi matematik: Apa, mengapa, dan bagaimana dikembangkan pada peserta didik. [Online]. Tersedia: http://math.sps.upi.edu/wp-content/upload/2010/02/ BERPIKIR-DANDISPOSISI-MATEMATIK-SPS-2010.pdf. [10 Mei 2011]. 